\title{
Discursive Tensions in Green Care - Communication, Collaboration and Policy Formation
}

\author{
Mark S. Hopfenbeck \\ NTNU, Norway \\ E-mail: Mark.Hopfenbeck@NTNU.no \\ Ragnfrid E. Kogstad \\ Hedmark University of Applied sciences, Norway \\ E-mail: Ragnfrid.Kogstad@hihm.no \\ Jan Kaare Hummelvoll \\ University College of Southeast Norway \\ E-mail: Jankhum@online.no
}

Received: November 11, 2015 Accepted: March 30, $2016 \quad$ Published: April 4, 2016

doi: 10.5296/jsss.v3i2.8059

URL: http://dx.doi.org/10.5296/jsss.v3i2.8059

\begin{abstract}
This article investigates how discursive tensions concerning language use and worldviews amongst Norwegian actors in Green Care services influence communication, collaboration and the dynamics of policy formation. The study combines qualitative content analysis and discourse analysis based on individual interviews and multi-stage focus group interviews. It focuses on a critical perspective in the analysis of interests and perspectives that dominate the field of Green Care. The study shows how Green Care is understood based on the actors' perceptions of the users' problem situation and their recovery process. The results also highlight the conditions for good communication and collaboration amongst the actors in the field. The overarching challenge for the actors involved is in creating cultural change where both the 'green' and 'care' are seen as legitimate qualities. Green Care must be continually explored and nuanced based on the healing potential inherent in both nature and basic human compassion. Adequate meeting places for the actors involved should be established in order
\end{abstract}


to develop a mutual understanding of each other's interests, intentions and perspectives. In doing so Green Care can become a form of social and environmental entrepreneurship integrating the value of community, the autonomy of individual voices, natural and social connectedness, and the importance of supportive relationships on the path towards recovery.

Keywords: Green Care; recovery; mental health; qualitative content analysis; discourse analysis

\section{Introduction}

"Green Care" is defined as the use of commercial farms and landscapes for promoting mental and physical health. It is part of a growing movement to provide health, social or educational benefits through the therapeutic use of nature (Hine et al., 2008). Based on partnerships between farmers, health and social care providers and participants the aim is to develop innovative, interdisciplinary services whereby various aspects of health care are integrated into forestry and agricultural activities and thereby strengthening both sectors (Haubenhofer et al., 2010).

The historical development of Green Care has varied between the different European countries. In the Netherlands, the development has taken place on the basis of productive farms, while in Germany 'green' services arose as a part of health care. In Norway the development of Green Care was originally the result of the combined need for farm holidays for children of parents needing a rest and as an economic adaptation of agriculture (Strandli et al., 2003).

Throughout Europe there seems to be a broad agreement regarding the need for a different approach to health and social services. Especially persons with mental health problems must increasingly be met with flexibility, close individual supervision, safe environments, good relationships, continuity and support for coping. Many of these qualities are found in Green Care and, there is general consensus that green services can be adapted to provide health benefits through the development of flexible services tailored to individual needs based on the different types of capital that Green Care represents. However, it seems difficult to realize Green Care's potential within the present system that is primarily designed to administer occupational rehabilitation.

A central orientation in contemporary mental health care is the recovery perspective (Anthony, 1993; Deegan, 1996; Topor, 2004; Davidson et al., 2005; Kogstad et al., 2011; Kogstad et al., 2014; Granerud \& Eriksson, 2014). A user-oriented recovery philosophy does not seem to be consistent with the documentation requirements, standardization, excessive bureaucratization and a service outcome focused first and foremost on getting people back to work. There is therefore a need for more research regarding how recovery practices are articulated in different health and social services and, how Green Care is affected by various administrative approaches, views of human nature, political agendas and conflicting professional interests.

Research on the relationship between nature and human health is still in its infancy (De Vries, 2006), but initial findings show positive changes with regard to general health, self-confidence, ability to deal with problems, to take responsibility, experience meaning, physical health and social skills (Hassnik \& van Dijk, 2006; Sempik, 2010). Central processes involved include stress reduction, physical activity and the facilitating positive 
social contact and personal development. However, we still lack insight into how nature-based services can best be organized to provide health benefits. Researchers have studied the relationship between the relevant factors and specific health outcomes (O'Brian \& Murray, 2007; Grahn, 2009), yet it is problematic with simple dose-response relationships in this field (Whitelaw, 2012). This presents a major challenge to policy formation which aims to apply agricultural resources, farmers' skills and environmental diversity to the development of a diverse and wide range of services within health, social and educational sectors, while helping to increase the quality of life for service users and increased employment and productivity in agriculture. The dynamics are made more complicated by the interactions between actors whom have partly overlapping and partly contradictory motives and objectives.

The aim of this article is to investigate how the discursive tensions involved in language use and worldviews among participants in Green Care influence communication, collaboration and the dynamics of policy formation. Our analysis therefore focuses on how language reflects, and in turn helps create, the social order. Consequently, we wanted to investigate the following questions:

- How is Green Care understood and described by the various stakeholders' and partners' perspectives?

-Which terms are used when "problem situations" (such as mental and physical health status, diagnostic groups and social situation) are described for those offered the service?

-What understandings of possible recovery processes emerge from the different actors?

- What are the conditions for good communication and cooperation between the parties involved in Green Care?

\section{Methods}

The study applies a combined qualitative content analysis (Elo \& Kyngäs, 2008) and discourse analysis (Hajer, 1995; Hajer \& Versteeg, 2005) based on material from individual and focus group interviews. There are two main types of discourse analysis: sociolinguistic text analysis and critical perspective in the identification and analysis of interests (Jaworski \& Coupland, 2006). This study focuses on the latter and aims to identify interests, clarify discourses and examine the perspectives that dominate the field of Green Care.

\subsection{Data Creation}

Data was created through both individual interviews and multi-stage focus group interviews (Hummelvoll, 2010) with participants from the county agricultural authorities, Norwegian Labour and Welfare Administration (hereafter: NAV), Green Care-providers and participants (service users, age 20-30 who had dropped out of school and work). Altogether 16 persons participated from various municipalities in a single Norwegian county from March to November 2011. The interviews were conducted first with homogeneous groups (providers; NAV employees; service users) who in different ways were involved in Green Care services. This was followed by focus groups with participants and representatives of the different areas together (agricultural, health and social sectors) with emphasis on how Green Care can help in the rehabilitation and recovery process for the participants. Focus group interviews were used in order to provide the opportunity to examine the concurrence, disparities and tensions 
between official guidelines and rationale for Green Care and various local justifications for what is actually done in the field.

\subsection{Ad focus Group Interviews}

In focus group interviews the researcher creates data based on dialogue in a group (4-12 participants) related to a focused topic that is determined in advance. It is ideal for exploring people's experiences, opinions, wishes or problems (Tillgren \& Wallin, 1999) - or when seeking a deeper understanding of a phenomenon, the meaning and attitudes related to specific topics in a group (Maunsbach \& Dehlholm-Lambertsen, 1997). The method combines group dynamic elements and a qualitative approach to produce good quality data. In focus group interviews variety and breadth of views is an explicit goal, which means that both consensus and divergence in perceptions and experiences related to the topic will be analyzed and investigated. The goal is not to reach a unanimous opinion, but to ensure breadth, variety and nuances in a way that gives a comprehensive presentation of the topic being studied (Hummelvoll, 2010).

Themes and problem formulations in this investigation were based on our discourse analytic interest in Green Care. A relatively open interview guide related to the four research questions guided the interview. In order to create an open and inquiring atmosphere, everyone's views and experiences were valued and greeted with interest.

The focus group interviews were led by a moderator and one or two co-moderators (who also wrote field notes), and were documented through notes and electronic recordings used to control the notes through playback. The researchers summarized the interview (including analytical interpretations), which was then sent to the participants and provided the basis for the next interview.

\subsection{Analysis}

The data were analyzed using a qualitative content analysis within a discourse analytic approach (Jaworski \& Coupland, 2006). In the analysis, we emphasized the statements related to roles, positions, power, shared representations or lack thereof, as well as what is considered valid knowledge and what is contested. The analysis of the statements sought to localize value structures as well as how meaning is constructed and identity attributed to different actors. The authors met regularly to discuss our interpretations and the development of the analysis. We focused continuously on the concrete language use of the participants and in particular the exchange of statements and responses concerning points of contention during the focus group interviews. As our interest was in part to uncover the underlying worldviews of the actors involved, the interviews were repeatedly "interrogated to uncover the unspoken and unstated assumptions implicit within them that have shaped the very form of the text in the first place" (Cheek, 2004). We arrived at a categorization based on what the actors perceive as the basic dimensions regarding Green care, users' "problem situation", recovery processes and conditions for communication and collaboration.

\subsection{Ethical Considerations}

Participation was based on a voluntary written consent. The consent form included an information sheet about the study that was sent to potential informants. The material was anonymized so that it is not possible to associate statements with individuals. Recorded audio 
files are stored securely on a separate external hard drive so that only the researchers have access. The audio files will be deleted after the study is completed.

The Declaration of Helsinki (2002) was followed by taking into account the principles of autonomy, beneficence, non-maleficence and fairness. There was reason to believe that participants would find it meaningful to articulate the experience of participation in Green Care, and to present views on how this service can be improved with respect to communication and collaboration.

\section{Results}

In the following we will describe how Green Care was understood by the actors involved in the study, how the users' problem situation are viewed and named, followed by four perspectives on the users' recovery processes and, finally highlighting important conditions for good communication and collaboration amongst the actors in the field.

\subsection{Actors' understanding of Green Care}

Green Care involves a nuanced concept of care, which includes three relational positions: 1) care understood as 'taking care of', 2) care understood as being interested in or 'caring about', and 3) care understood as mutual care, i.e. 'caring with'. These three understandings of care relate to both the relationship and interaction between people and between people and nature. The "green" aspect of Green Care has reference to different understandings of the rural environment and nature as:

- Living space (natural capital): This is the expansive green physical space that surrounds us. One feels safe, there is room for the individual - and nature not only protects, but also provides. Key statement: "Everyone benefits from Green Care - nature has room for all of us."

- Retreat (spiritual capital): Nature can be a haven or sanctuary. The scenery invites to meditation, intimacy, connection and attachment to the place, the landscape and nature. Key statement: "Nature provides peace of mind - help to find oneself."

- Community (social capital): Being on the farm is a shared task that demands work from everyone. Community is characterized by norms, trust and networks. It becomes obvious when someone is away or not doing his/her job; one is part of a whole from start to finish. It creates meaning in the work and helps to prevent alienation. One grows to be responsible. Key statement: "Working with animals helps one to be social ... Everyone is contributing as needed on the farm."

- Activity and learning space (cultural capital): Nature and the farm provide the opportunity to master practical tasks connecting one with the material world. Opportunities are created to experience personal competency and a positive identity as the work is useful and gives visible results. Key statement: "Nature and the farm can also be understood as an extended classroom without walls - a freer arena where nature is seen as a teacher - and where you can learn new skills and even learn something you never knew you needed."

Though there is a mutual recognition of the importance of these forms of Green Care capital, there is considerable disagreement between the actors regarding their relative importance. Providers understand Green Care as a way of life and a sense of belonging - and as social commitment. The environment is a natural context for human endeavor creating cultural 
landscapes and thriving local communities. The caring aspect is embedded in meaningful activities while engaging the lives of persons having dropped out of school and working life and supporting them to find peace of mind. This engagement, the providers hold, "must come from the heart".

$N A V$ base their understanding on an administrative and goal-oriented perspective. Green Care represents an alternative setting for rehabilitation. It provides an arena for work in a new context. Potentially it builds self-confidence through experience of successful coping. Green Care is about finding resources and seeing things grow and thrive. It is an opportunity for people who are far away from the labour market, and provides them with structure.

Users base their understandings on their subjective life experiences and personal knowledge. Green Care creates freedom and peace and opportunities for physical activity; nature challenges without being overwhelming; encounters with animals can result in an experience of unconditional acceptance; participation in the social life of a farm helps one feel included and find one's place in society and in nature.

\subsection{Description of Users' "Problem Situation"}

Users' problem situation (e.g. health condition, diagnosis and social situation) was associated with two "worlds"; the life-world and the system-world. Problem situations can be grouped as follows:

- Existential issues (life-world problem): Many of the problems that the users experienced were related to their well-being and coping with everyday life. The search for meaning and a future that offers valuable activities was a challenging process for many of the users, as it requires motivation, hope and skills. Many of the users had the experience of not being accepted, appreciated or valued which resulted in anxiety, loneliness and depression.

- Social issues (system-world problems): Users experienced falling short in their meetings with the community's expectations and requirements. Lack of social participation in terms of not completing schooling and being unemployed over time lead to marginalization, exclusion and an experience of being stigmatized. They described having lost confidence in the government's ability to meet them on their own terms, which seemed to have contributed to their sense of powerlessness and alienation.

Providers base their understanding on "common sense", their own life experiences and their ability to 'see' the individual user. Those who come to Green Care services are often 'drop-outs' who are tired of school, have anxiety for classrooms and have substance abuse problems. They are often people who experience difficulties in adjusting to the demands of society and the educational system. The providers seem to identify with this 'underdog' mentality, 'out of the box' experience and realize that what is needed usually is structure, attention to the person's needs and an appreciation of them as individuals.

$N A V$ base their understanding on the idea of civic rights and obligations as fundamental to social participation. They tend to see the users' problems in terms of the absence of daily routines and social norms combined with a lack of skills, which leads to social problems and marginalization.

Users base their problem descriptions on their own experience and self-understanding of being in an outsider position with regards to school and the workplace. They expressed 
feelings of being unloved, finding themselves stressed with a lack of belief in their ability to finish school. They reported not having anyone to talk to, feeling afraid of being themselves, yet not daring to speak with anyone for fear of ridicule. Many said that they had lost hope and meaning - and felt that using drugs was the only thing that gave them some sense of relief.

\subsection{Perspectives on the Recovery Process}

The analysis of data revealed four perspectives that in varying degrees are seen as essential for helping the users improve their life situation.

- The green perspective: Nature and the sense of naturalness involved in working on the farm are perceived by many as reducing stress. The natural environment provides ample opportunity for experiences, which lead to feelings of autonomy and security. The variety of farm activities also allows for a 'natural' fit between skills and tasks. Contact with and care for animals provides an opportunity for young people to experience themselves in a role of responsibility for another being in which they can explore their own care-giving skills.

- The dignity perspective: An important prerequisite for improvement seems to be the experience of being treated with respect and dignity. In a situation where many of the users have been judged to be 'not good enough', the experience of being accepted and recognized for who they are, is often the first step towards developing positive self-esteem. Through a focus on dialogue and compassion, the cultivation of positive personal relationships creates conditions for lasting change.

- The social perspective: The farm seems to provide unique opportunities for the development of a safe social community. The need for non-structured collaboration around common tasks and goals creates recurring situations where users must improvise and help each other find appropriate solutions to practical problems. In such a context, the farmer's ability to lead a working partnership with patience, empathy and understanding is essential to the development of a sense of belonging and mutual trust among the users. The users are also an important source of social support for each other. By sharing their personal stories they have the opportunity to reflect on their past and plan their future together with others with similar life experiences.

- The competence perspective: The farm offers many concrete and varied learning opportunities. The tasks range from the most simple, routine tasks to the complex requiring expert guidance over time. Thus, skill training can be tailored to the individual's aptitude while at the same time making one's own development very evident. Many tasks are quite practical, requiring physical effort, which helps to energize and motivate users. Development of one's social and practical competence leads to feelings of mastery and self-efficacy, which in turn contributes to the individual's recovery process.

Providers highlight the importance of commitment, authenticity and willingness to dialogue with the users. Recovery entails users not being labeled and put in traditional categories, but recognized as individuals deserving respect and acceptance for who you are. The farm should be a place where people are cared for and believed in while being given the time and opportunity to build up what has been torn down.

$N A V$ focuses on the importance of structuring everyday life, so that those involved can get started on a positive path towards employment. Time on the farm is seen as a form for 
restitution or convalescence, which cultivates a sense of control and directedness.

Users point to the importance of informal peer-support, self-help and good leaders. A good leader is a compassionate role-model with strong relationship skills and practical know-how. These leaders are able to ensure that the users feel that they are doing a real job, making a significant contribution and belong to something greater than themselves.

\subsection{Conditions for Good Communication and Cooperation between the Parties}

There are four conditions, which were cited as essential for good communication and cooperation:

- Dialogical attitude: A basic requirement for good communication is that the people involved are willing to listen to each other and have a sincere desire for mutual understanding. This requires a humility and curiosity so that one avoids their own biases and is able to meet others on their own terms when developing common goals.

- Trust and confidence: Cooperation assumes that actors bring with them a sense of joint task and a belief in their ability to achieve communal goals. Such confidence is a basic premise for cooperation and a starting point for the development of mutual trust.

- Respect and equality: Collaboration is a complex interaction involving the attainment of multiple goals. Different actors will be primarily concerned with their own tasks and objectives and it is not always easy to see how these will be reconciled. To succeed, it is important that the actors recognize each other as equals and have mutual respect for what the others are trying to accomplish.

- Individually adapted and flexible: The services being developed aim to help the user achieve their goals. Often the user needs a lot of time and help to find an appropriate path towards recovery. It is, therefore, important that cooperation is based on a large degree of flexibility and openness to a high level of user control, which allows for individual adaptations.

The providers experience themselves to be at the mercy of NAV services and are at times frustrated with what they felt was a lack of flexibility. The providers were skeptical of some of the processes involved and found themselves questioning the fairness of the decisions being made regarding what kind of services were financed and wondering whether the resistance to further developments was related to competing professional interests. Quality assurance was also a recurrent topic of discussion. Providers challenged dominant ideas about quality assurance and what they experienced as an excessive reliance on control based on the filling out of forms.

To their defense $N A V$ pointed to the large number of farmers involved and the lack of an organizational model that could simplify the various processes. As a consequence, there is a tendency to rely on intermediary companies who are able to coordinate supply and demand and have a more active role in the quality assurance process. This does seem to generate increasing levels of professionalism, and may impede direct contact between the providers and the welfare services making communication and coordination more difficult.

Users express that a sense of belongingness and trust within the group, and with the farmer, is of the utmost importance. Participants must feel that they fit in and that they are working towards a common goal. The providers - as well as the welfare services - must relate to the 
users as individual persons with specific needs, strengths and challenges. A realistic attitude implies an acceptance that participants may fail or make mistakes. For the users it is important to create situations where everyone is able to relax together as when they are outdoors around a fire where conversations often turn to plans for the future based on a renewed hope and belief in oneself.

\section{Discursive Tensions}

In the interviews we examined in detail how the different discourses unfolded and interacted in practice. We found that the focus group interviews as shared conversations brought the differing discourses closer to each other while at the same time uncovering contested positions and perspectives that exist between the discourses on a deeper level. In the following we will describe some of these discursive tensions in more detail.

\subsection{Manualization and Standardized Quality Assurance Versus Flexibility and Quality by Personal Presence}

It is necessary that the "buyers" of Green Care (i.e., NAV, health and social services) have sufficient information regarding the services they are interested in purchasing. From the buyers' perspective this information should be based on some basic common assumptions regarding how quality can be documented as being relevant to health and social policy guidelines.

The challenge from the providers' perspective is to present that which is fairly ordinary (i.e. being outside, in nature) as a sufficiently extraordinary product that others are willing to buy it. In addition, one hopes to convey that the "product" is not only relevant and effective; it also has an intrinsic value not provided by traditional health and social services. The aim is that this unique quality is communicated in such a way that it can be recognized as a deeply felt human experience leading to recovery within a natural setting where the individual can find a balance of autonomy and responsibility.

The idea of quality is thus a core concept for the various actors in the Green Care field and yet described by each of them differently. Health services generally describe services of high quality as those that are effective, safe and efficient (Grepperud, 2009). Users usually value these characteristics, but the immediate experience of how the services are perceived as meeting ones' expectations and needs are often given precedence. The providers often evaluate themselves according to their values and ideals; a good provider is a compassionate amateur whose motivation is 'heartfelt' as opposed to those who are perceived as professional, economic actors. They saw their own expertise as a personal ability to 'see' where the participant is at any one time, establish a trusting relationship and find flexible, individually tailored solutions. The NAV-representatives argued that quality is the strict adherence to standardized procedures including the quantification and measurement of well-defined criteria.

These tensions between what can be considered a New Public Management discourse based on market mechanisms, competitive procurement and the rationalization of services, and a "provider discourse" where there is an emphasis on flexibility, proximity and a 'good heart', reflect wider societal conflicts regarding the form and content of human services. The ideology of manualization and standardization often dominates policy discussions, but is 
continually challenged by the lived experience and research on what works in recovery; equal dialogue, flexibility, individual attention, confidence and trust (e.g. Thomas, Bracken \& Timimi, 2012).

\subsection{The User Perspective and Expert Planning: Bottom-Up Versus Top-Down}

Despite the rhetoric in recent years focusing heavily on the user perspective and consumer involvement, tensions exist between a user and a planning discourse. The users (and to a certain extent the providers) attach great importance to the individual as a driving force in service development in order to meet their needs for self-esteem, confidence and mastery. In meetings between the actors, the social welfare representatives supported this ideology in theory, but they also emphasized the need for a regulated, structured, incentive-based planning of the individual's return to productive employment. This is an expression of the principle known as 'the work approach' ('arbeidslinjen', cf. Norwegian Ministry of Labour, 2012) with the explicit goal of return to employment. This leads to an individualizing discourse where people are pushed to find their place in the labour market while disregarding structural problems in the form of the relevant labour demand, fragmented services, poverty, discrimination, marginalization and the stigmatization of personal crises. The combination of these factors means that a large proportion of individuals struggle with poor self-esteem as a result of repeated adverse experiences to such an extent that they may need a considerable amount of time to build up a minimum of confidence and sense of achievement before they can participate in the regular labour market.

The distance between bottom-up and top-down perspective is also reflected in policy processes for the social welfare sector. New programmes are rarely user-initiated and the content increasingly involves more control at the cost of flexibility. While temporary sheltered employment and job placement have long been a prevailing trend, the gold standard now is individual placement and support. Direct placement in the workplace, however, without the benefits that come from a sense of choice and self-determination including, if needed, a gradual, user-directed recovery process, risks either postponing or even hindering a natural and necessary period of growth and development.

\subsection{Productivity Versus Recovery}

Society is dominated by productivity requirements. As social welfare services have to a large extent limited themselves to vocational rehabilitation, there is a risk of a sharper distinction between 'productive' and 'non-productive' persons, defined by their relationship to work. The risk of marginalization of persons outside the productive labour sphere is therefore greater. In Norway, the percentage of persons between 16 and 67 who receive Social Security benefits is over $11 \%$. Almost $60 \%$ of those receiving Social Security benefits do so as a result of mental illness or musculoskeletal complaints (cf. Folkehelseinstituttet, 2010/2012). Many of these persons do not have jobs and potentially will not have stable employment for the foreseeable future. For these persons, facilitating daily activities and quality of life is of primary importance whether one has a job or not. Standing outside the workplace is not synonymous with being passive. In our society we have a challenge to appreciate the creative contributions of individuals within families, organizations and communities regardless of where one's income comes from. 


\section{Macrothink}

Journal of Social Science Studies

ISSN 2329-9150

2016, Vol. 3, No. 2

The demand of productivity, and the sharp distinction between those within the labour sphere and those outside, can contribute to marginalization. Increasing the number of stops along the way with more fluid transitions between them and a different view of being in the process, will likely help more people live more rewarding lives and potentially participate in the labour market again. The recovery tradition in our context is based on users' subjective experiences (Anthony, 1993; Deegan, 1996; Davidsson et al., 2005). Two important elements of this tradition are 1) that the individual's ability to live a satisfying life has a value in itself and 2) that mental illness is something most people can recover from. The primary goal is to facilitate hope, trust, dignity, social networks and the satisfaction of universal, psychosocial and material human needs. If we are able to avoid the social stigma of presumed chronicity, trust in the individuals self-healing powers, minimize our focus on function and productivity, and support the individual's struggles to regain a sense of meaning, hope and dignity, we may paradoxically enough, help more back to lives of education, employment and civic participation.

\subsection{Health and Social Care Professionalism and Green Care Professionalism}

That which is genuinely professional in promoting health and well-being through the use of nature is not predefined. One "borrows" the professionalism of the health and social sciences as both an addition to the Green Care professionalism and as a legitimization of professional responsibility. But is it given that nature-based services or Green Care should be a health or social care discipline? The question is important and parallel to the issue of whether persons whom are struggling mentally, first and foremost need expert medical help or assistance of a more philosophical, cultural, economic, practical, educational or spiritual nature.

The social welfare service's professionalism was associated with the health and social care, but the providers and users were more concerned with a type of relational competence including being compassionate, doing things together, having time to talk about personal, existential issues, expressing positive expectations, being generous, sharing an understanding and appreciation of nature, showing respect and allowing the individuals the opportunity to find peace of mind.

Regarding factors of importance for the recovery process in Green Care, we have, as previously mentioned, identified four perspectives. The green perspective entails helping the person to experience an ecological connectedness and the tranquility, the sensations, and the beauty of the natural world. The dignity perspective is based upon recognition of one's integrity and intrinsic worth communicated through compassionate dialogue. The social perspective is facilitated by the saliency of a work community created around meaningful and creative activities in the special interpersonal contexts, which arise around a campfire, in a "Lavo", or in a clearing. The competence perspective requires that the person and the task are matched together such that the task is challenging, yet attainable.

Green Care professionalism is built upon the ability to incorporate all of these perspectives while at the same time being both work leader and employer. There seems to be a need to develop a language for this type of approach, which is able to both challenge and complement the health and social care professionalism in Green Care and nature-based services. It is about a compassionate commitment, equality, and the ability to let nature contribute to learning together with a guide who embodies an in-depth knowledge of the complex dynamics of 
nature. This is a different kind of expertise than the clinical gaze of health care professionalism. It is a unique and valuable kind of professionalism, which needs to be appreciated by those who currently work with people who are at risk of being marginalized in terms of education and employment.

\subsection{Short-Term Profits Versus Long-Term Sustainability}

Finally, there are tensions associated with the ideas of profitability and service transformation. A characteristic of Green Care services, as in many other welfare innovations, is that they are often project-based. This organizational form lacks the stability to sustain long-term investment on part of those willing to develop and manage the services. As projects they are fundamentally limited and not necessarily intended to become established practice. In our search for good examples, it was apparent that a major hindrance was that 'good practices' were not given sufficient time to mature and develop.

To create stability and predictability, and hence sustainability, an institutional framework for ongoing transactions between buyers, users and providers must be designed to minimize transaction costs. The market for the farmer as a producer needs to be stabilized in order to reduce the risk involved in human as well as capital investments. Although the development of Green Care services is partly driven by changing political solutions to marginalization and exclusion, this should not prevent the establishment of mechanisms to ensure continuity of demand.

Project-based initiatives signal that good-enough solutions do not yet exist and that there are opportunities for novel, not yet proven, arrangements. Naturally, one can find new and better solutions by continual innovation, but the downside is that this may remove the focus from the fulfillment of basic human needs. What it takes to give persons back their confidence, motivation and sense of self-worth, is not as mysterious as the changing political solutions may suggest.

Policy risks becoming ambiguous when the search for adequate interventions becomes too tightly interwoven with the quest for cheaper solutions. Finding the balance between effectiveness and efficiency is complicated (Weiss, 1981), and in the perspective of long-term sustainability it is uncertain whether "better and cheaper" is a realizable goal.

\section{Conclusion - Productive Tensions}

Key actors seem to be unanimous in their emphasis on the need for well-developed Green Care services. Farmers want to offer Green Care services both to enhance the farm financially, but also to help users. Political authorities clearly state that the development of green services can contribute to vibrant rural communities based on the farm as a framework for flexible, safe, individualized services including people who are struggling with substance abuse and mental health problems.

There is general consensus that Green Care services can be adapted to provide health benefits through an interaction of both natural and social factors so that the user can both 'Be' and 'Become'. The different types of capital that Green Care represents make it possible to develop flexible services that are tailored to the individual. This gives the user the opportunity to meet various challenges on the existential, social and practical level, at their own pace. When Green Care services can provide opportunities for mastery and autonomy as 
well as the acceptance and recognition in a social community, it creates positive conditions for recovery.

Yet, it is difficult to realize the potential that most players see Green Care as representing. The different actors seem to operate under different logics that are difficult to reconcile. Recovery with its focus on openness, trust and equality is not necessarily consistent with standardization, bureaucratization and 'the back-to-work approach'. The opposing power relations were very apparent between the discourses we have outlined. An overreliance on manualization and standardized quality assurance seems omnipresent, top-down planning dominates bottom-up involvement, being productive has a higher status than being well, health and social care professionalism is more valued than Green Care professionalism and, last but not least, short-term profitability seems to inevitably supersede long-term sustainability in almost all areas of policy.

The counter discourses are not, however, entirely powerless. There was an acknowledgement that the rationality of the New Public Management (NPM) can at times feel hegemonic. There was also a general consensus that a one-sided focus on efficiency and control can prevent a more comprehensive and long-term development of the services (Kinn et al., 2012). More important for those interviewed was a desire to safeguard existing values expressed through the various forms of Green Care capital. There was a felt need, and to some a strongly felt obligation, to challenge the formal, bureaucratic language based on rules and regulations with a more humanizing, experience-near, everyday language as it is used in the discussion of, and interaction with, Green Care activities. The inherent tensions within these two perspectives create the need for continual negotiations and translations enabling communication and collaboration conducive to the formation of coherent policy.

These tensions can become productive if Green Care can function as a 'boundary object' for the various actors, i.e. objects or concepts that are plastic but robust enough to maintain a common understanding across sites (Star \& Griesemer, 1989).

According to Star and Griesemer boundary objects can develop as the result of a 'central tension' arising when a diverse group of actors with divergent viewpoints are required to cooperate. Vik and Farstad (2009) make the argument that there is no such boundary object within the world of Green Care around which the diverse actors can gather. Our conclusion based on this study, however, is that Green Care itself, as an idea and a practice, can and already does to a certain extent, function as a boundary object helping actors to "translate, negotiate, debate, triangulate and simplify in order to work together" (Star and Griesemer, 1989:389).

It appears that the overarching challenge for all actors involved is a slow cultural change where both the 'green' and 'care' are seen as legitimate qualities. Green Care must, in our opinion, be continually explored and nuanced based on the potential inherent in both Nature and basic human compassion. We must create adequate meeting places for the actors involved so that they can develop a mutual understanding of each other's interests, intentions and perspectives. In doing so Green Care can become a form of social and environmental entrepreneurship, which with renewed force, can point to the value of community, the autonomy of individual voices, natural and social connectedness, and the importance of others on the path towards recovery. 


\section{References}

Anthony, W. A. (1993). Recovery from mental illness: The guiding vision of the mental health service system in the 1990s. Psychosocial Rehabilitation Journal, 16(4), 11-23. http://dx.doi.org/10.1037/h0095655

Cheek, J. (2004). At the margins? Discourse analysis and qualitative research. Qualitative Health Research, 14, 1140-1150. http://dx.doi.org/10.1177/1049732304266820

Davidson, L., O’Connel, M. J., Tandora, J., Lawless, M., \& Evans, A. C. (2005). Recovery in Serious Mental Illness: A New Wine or Just a New Bottle? Professional Psychology: Research and Practice, 36(5), 480-487. http://dx.doi.org/10.1037/0735-7028.36.5.480

Deegan, P. (1996). Recovery and the Conspiracy of Hope. Paper presented to the Sixth Annual Mental Health Services Conference of Australia and New Zealand, Brisbane, Australia.

De Vries, S. (2006). Contribution of natural elements and areas in residential environments to human health and wellbeing, In J. Hassnik, \& M. Van Dijk (Eds.). Farming for health. Proceedings of the Frontis Workshop on Farming for Health. Wageningen, The Netherlands, 16.-19. March 2005. http://dx.doi.org/10.1007/1-4020-4541-7_2

Elo, S., \& Kyngäs, H. (2008). The qualitative content analysis process. Journal of Advanced Nursing, 62, 107-115. http://dx.doi.org/10.1111/j.1365-2648.2007.04569.x

Folkehelseinstituttet. (2012). Arbeid trygd og helse - Faktaark med statistikk 2010, Oppdatert 16.10.2012.

Grepperud, S. (2009). Kvalitet i helsetjenesten - hva menes egentlig? Tidsskr Nor Legeforen, 129, 1112-1114. http://dx.doi.org/10.4045/tidsskr.08.0377

Grahn, P. (2009). Naturen som friskfaktor. Powerpointpresentasjon. Område Arbetsvetenskap Ekonomi och Miljöpsykologi, SLU Alnarp

Granerud, A., \& Eriksson, B. (2014). Mental Health Problems, Recovery, and the Impact of Green Care Services: A Qualitative, Participant-Focused Approach. Occupational Therapy in Mental Health, 30(4), 317-336. http://dx.doi.org/10.1080/0164212X.2014.938558

Haas, P. (1992). Introduction: Epistemic communities and international policy coordination. International Organization, 46(1), 1-36. http://dx.doi.org/10.1017/S0020818300001442

Hajer, M. (1995). The Politics of Environmental Discourse: Ecological Modernisation and the Policy Process. Oxford: Clarendon Press.

Hajer, M., \& Versteeg, W. (2005). A decade of discourse analysis of environmental politics: Achievements, challenges, perspectives. Journal of Environmental Policy and Planning, 7(3), 175-184. http://dx.doi.org/10.1080/15239080500339646

Hassnik, J., \& Van Dijk, M. (2006). Farming for health. Proceedings of the Frontis Workshop on Farming for Health Wageningen, The Netherlands 16.-19. March 2005. http://dx.doi.org/10.1007/1-4020-4541-7

Haubenhofer, D., Elings, M., Hassink, J., \& Hine, R. E. (2010). The development of Green Care in Western European countries. Explore, 6, 106-111. http://dx.doi.org/10.1016/j.explore.2009.12.002

Hine R., Peacock J., \& Pretty J. (2008). Care farming in the UK: evidence and opportunities. 
Report for the National Care Farming Initiative (UK). Department of Biological Sciences, University of Essex.

Hummelvoll, J. K. (2010). Flerstegsfokusgruppeintervju - en sentral metode i deltagerbasert og handlingsorientert forskningssamarbeid. Tidsskrift for Klinisk Sygeplejeforskning, 24(3), 4-13.

Jaworski, A., \& Coupland, N. (2006). The discourse reader. $2^{\text {nd }}$ edition. London: Routledge, Taylor \& Francis group.

Kinn, L.G., Ekeland, T-J., \& Byrkjeflot, H. (2012). Psykisk helsearbeid: konfeksjon eller skreddersøm? Tidsskrift for Velferdsforskning, 15(1), 23-36.

Kogstad, R. E., Ekeland, T.-J., \& Hummelvoll, J. K. (2011). In defence of a humanistic approach to mental health care: recovery processes investigated with help of clients' narratives on turning points and processes of gradual change. Journal of Psychiatric and Mental Health Nursing, 18, 479-486. http://dx.doi.org/10.1111/j.1365-2850.2011.01695.x

Kogstad, R. E., Agdal, R., \& Hopfenbeck, M. S. (2014). Narratives of Natural Recovery: Youth Experience of Social Inclusion through Green Care. Int. J. Environ. Res. Public Health, 11, 6052-6068. http://dx.doi.org/10.3390/ijerph110606052

Maunsbach, M., \& Dehlholm-Lambertsen, B. (1997). Det fokuserede gruppeinterview og deltagerobservasjon. Nordisk Medicin, 4, 126-128.

O'Brian, L., \& Murray, R. (2007). Forest School and its impact on young children: Case studies in Britain. Urban Forestry and Urban Greening, 6, 249-265. http://dx.doi.org/10.1016/j.ufug.2007.03.006

Sosial- og helsedirektoratet. (2005). Arbeidsrettede tiltak for personer med psykiske problemer. En systematisk oppsummering av internasjonal effektforskning.

Star, S. L., \& Griesemer, J. R. (1989). Institutional Ecology, 'Translations' and Boundary Objects: Amateurs and Professionals in Berkley's Museum of Vertebrate Zoology, 1907-39. Social Studies of Science, 19, 387-420. http://dx.doi.org/10.1177/030631289019003001

Strandli, B., Hoel, K., Bjørn, V., Larsen K., Grimsæth, Ø., Hunskaar, Ø., \& Bentsen, P. (2003). Grønn omsorg mot år 2000. Rapport fra prosjektet i Vestfold 1998-2003.

The Declaration of Helsinki. (2002). Ethical Principles for Medical Research Involving Human Subjects.

Tillgren, P., \& Wallin, E. (1999). Fokusgrupper - historik, struktur och tillämpning. Socialmedicinsk Tidskrift, 4, 312-321.

Thomas, P., Bracken, P., \& Timimi, S. (2012). The anomalies of evidence-based medicine in psychiatry: time to rethink the basis of mental health practice. Mental Health Review Journal, 17(3), 152-162. http://dx.doi.org/10.1108/13619321211287265

Topor, A. (2004). Vad hjälper? Vägar till återhämtning från svåra psykiska problem. Stockholm: Natur och Kultur.

Vik, J., \& Farstad, M. (2009). Green care governance: between market, policy and intersecting social worlds. Journal of Health Organization and Management, 23(5), 539-553. http://dx.doi.org/10.1108/14777260910984023

Weiss, J. (1981). Substance vs. symbol in administrative reform. The case of human services 
coordination. Political analysis, 7(1), 21-45.

Whitelaw, S. (2012). The emergence of a 'dose-response' analogy in the health improvement domain of public health: a critical review. Critical Public Health, 22(4), 427-440. http://dx.doi.org/10.1080/09581596.2012.682147

\section{Copyright Disclaimer}

Copyright for this article is retained by the author(s), with first publication rights granted to the journal.

This is an open-access article distributed under the terms and conditions of the Creative Commons Attribution license (http://creativecommons.org/licenses/by/3.0/). 